\author{
Dominik J. Kościuk ${ }^{*}$
}

\title{
GWARANCJE PRAWNE OCHRONY PRAW PODMIOTOWYCH ABONENTA W POLSKIM PRAWIE TELEKOMUNIKACYJNYM
}

\section{Wstęp}

Ostatnia istotna nowelizacja ustawy Prawo telekomunikacyjne miała miejsce w styczniu 2013 r. ${ }^{1}$ Wprowadzono wówczas szereg zmian mających znaczenie z punktu widzenia praw konsumentów rynku telekomunikacyjnego. Nowe regulacje dotyczą między innymi: praw konsumenta w zakresie umów zawieranych w drodze elektronicznej, udogodnień w korzystaniu z Internetu mobilnego, ułatwień w dostępie do usług telekomunikacyjnych osób niepełnosprawnych, czy też ochrony prywatności i danych osobowych. Wydaje się, że większość tych zmian może wpływać na ochronę niektórych praw podmiotowych konsumentów na rynku telekomunikacyjnym. Co więcej, zdaje się, że nowelizacja wpłynęła również na większą ochronę publicznych praw podmiotowych. Aby jednak potwierdzić ową tezę, należy wykazać związek uprawnień konsumenta określonych w P.tel., $\mathrm{z}$ instytucją praw podmiotowych (i niejako ich publiczną odmianą) oraz dookreślić gwarancje prawne, faktycznie służące ochronie tych praw.

\section{Definicje praw podmiotowych i publicznych praw podmiotowych}

Wykazanie powiązań praw konsumenta usług telekomunikacyjnych oraz przedsiębiorcy działającego na właściwym rynku, z koncepcją praw podmiotowych (jak też publicznych praw podmiotowych), nie może się obejść bez uprzedniego wskazania czym są owe prawa. Między innymi, dużym stopniem ogólności charakteryzuje się definicja A. Wróbla, który przyjmuje niezwykle szerokie ujęcie praw podmiotowych, jako kategorię zbiorczą dla trzech sytuacji prawnych

* Dr, Katedra Prawa Administracyjnego, Wydział Prawa Uniwersytetu w Białymstoku.

${ }^{1}$ Ustawa z dn. 16 listopada 2012 o zmianie ustawy - Prawo telekomunikacyjne oraz niektórych innych ustaw, Dz. U. z 2012 r., poz. 1445. 
podmiotu: korzystania z prawa do czegoś, wolności i posiadania kompetencji². W nieco starszej literaturze Z. Ziembiński odnosił to pojęcie do funkcjonalnie powiązanych wolności, uprawnień i kompetencji danego podmiotu ${ }^{3}$, a A. Wolter pisał, że jest to „przyznana przez przepisy prawne i wynikająca ze stosunku prawnego sfera możności postępowania osoby fizycznej lub prawnej w określony sposób, umożliwiająca ochronę interesów uprawnionego, tylko w granicach zakreślonych przez przepisy prawne"4.

Natomiast publiczne prawo podmiotowe definiowane jest jako sytuacja prawna obywatela, w ramach której może on skutecznie żądać czegoś od państwa lub może w sposób niekwestionowany przez państwo coś zdziałać. J. Zimmermann pisze, że owe prawa to „sytuacje, w których od zachowania konkretnej osoby stojącej poza władzą publiczną zależy, czy dla tej władzy powstanie obowiązek oparty na prawie (wynikający z prawa)", i uzupełnia definicję o wyjaśnienie, że podmiot posiadający publiczne prawo podmiotowe ma uprawnienie do samodzielnego wyznaczania obowiązków administracji publicznej w ustalonym za$\mathrm{kresie}^{6}$. Z kolei P. Przybysz wskazuje, że organ administracji, mając do czynienia z publicznym prawem podmiotowym, jest prawnie zobowiązany do postąpienia zgodnie z jego treścią, a zatem obywatel może żądać od administracji podjęcia pewnego działania bądź powstrzymania się od działalności, a w przypadku odmowy (niezrealizowania) może bronić swoich praw przed sądem administracyjnym $^{7}$. Niejako zbiorczą definicję przedstawia R. Suwaj pisząc, że to z porządku prawnego wynikają prawa jednostki względem państwa. Jednocześnie, ów autor podsumowuje istniejące $\mathrm{w}$ literaturze koncepcje rozumienia rzeczonych praw, wskazując, że mogą mieć treść pozytywną (i tym samym być rozumiane jako: roszczenie o wydanie aktu administracyjnego oznaczonej treści, żądanie od organu wydania decyzji bez wskazania na jej treść, domagania się określonych świadczeń pozytywnych, żądania od organu współdziałania w rozstrzyganiu spraw publicznych i żądaniu udziału w działaniach państwa) oraz negatywną - jako roszczenie o zaniechanie ingerencji państwa w sferę uznanej uprzednio wolności lub przyznanego stanu prawnego ${ }^{8}$.

2 A. Wróbel, Prawo podmiotowe publiczne, [w:] R. Hauser, Z. Niewiadomski, A. Wróbel (red.), System prawa administracyjnego, t. 1, Instytucje prawa administracyjnego, Warszawa 2010, s. 340 .

3 Z. Ziembiński, Problemy podstawowe prawoznawstwa, Warszawa 1980, s. 365.

${ }^{4}$ A. Wolter, Prawo cywilne. Zarys części ogólnej, Warszawa 1967, s. 108.

5 J. Boć, Prawo administracyjne, Wrocław 2004, s. 519.

6 J. Zimmermann, Prawo administracyjne, Warszawa 2012, s. 284.

7 P. Przybysz, Publiczne prawa podmiotowe, [w:] red. M. Wierzbowski, J. Jagielski, J. Lang $\mathrm{i}$ in. (red.), Prawo administracyjne, Warszawa 2003, s. 124.

${ }^{8}$ R. Suwaj, Publiczne prawa podmiotowe, [w:] P.J. Suwaj (red.), Prawo administracyjne. Ćwiczenia, Warszawa 2011, s. 197-198. 


\section{Gwarancje ochrony praw podmiotowych}

Biorąc zatem pod uwagę tak dookreślone koncepcje praw podmiotowych oraz publicznych praw podmiotowych (a jednocześnie analizując ostatnie zmiany P.tel.), można - w celu wykazania istnienia gwarancji prawnych służących ich ochronie, w ramach działalności telekomunikacyjnej - dokonać próby wyodrębnienia pewnego rodzaju wzajemnych uprawnień (ale i jednocześnie obowiązków) konsumentów, przedsiębiorców telekomunikacyjnych oraz administracji publicznej. Wydaje się, że można do nich zaliczyć gwarancje prawne: ochrony konsumenta usług telekomunikacyjnych jako strony kontraktu, umożliwienia zawierania umów w formie elektronicznej, ochrony prawa abonenta do rzetelnej informacji, ochrony prawa do przeniesienia numeru do innego operatora $\mathrm{w}$ terminie jednego dnia, ochrony prywatności i danych osobowych oraz ułatwiania dostępu do usług i udogodnień dla osób niepełnosprawnych.

\section{Ochrona konsumenta usług telekomunikacyjnych jako strony kontraktu}

Nowelizacja przepisów Prawa telekomunikacyjnego ${ }^{9}$ dotyczy szeregu praw podmiotowych o charakterze konsumenckim. Przede wszystkim, zwiększono ochronę konsumentów zawierających umowy o świadczenie usług telekomunikacyjnych $^{10}$, ograniczając niejako negatywne dla konsumenta skutki ,adhezyjności” tego rodzaju kontraktów ${ }^{11}$. Do przepisu art. 57 ust. 6 p.tel. dodano normę wskazującą, że w razie jednostronnego rozwiązania umowy przez abonenta - do dnia rozpoczęcia świadczenia usług - przedsiębiorcy telekomunikacyjnemu nie przysługuje roszczenie o odszkodowanie. Dotychczas bowiem, konsument był

9 Ustawa z dn. 16 lipca 2004 r. Prawo telekomunikacyjne, Dz. U. nr 171, poz. 1800, ze zm. 9dalej p.tel.).

10 A. Krasuski (Umowa o świadczenie ustug telekomunikacyjnych, Warszawa 2005, s. 4045) wymienia i analizuje cztery rodzaje usług telekomunikacyjnych: usługa telekomunikacyjna (przekazywanie wszelkich sygnałów w sieciach telekomunikacyjnych, dostarczanie spisu abonentów, usługa przeniesienia numeru telefonicznego, udostępnianie informacji o numerach), publicznie dostępna usługa telekomunikacyjna (bez ograniczenia kręgu odbiorców), usługa powszechna (dostępna dla wszystkich użytkowników końcowych stacjonarnych publicznych sieci telefonicznych) oraz usługa o podwyższonej opłacie (0-700, 0701, 0-300 np. informacje o horoskopach)

${ }^{11}$ Analizą charakteru prawnego umów o świadczenie usług telekomunikacyjnych, w tym cechy ich jednostronności (adhezyjności) zajmowałem się w publikacji: D. Kościuk, Umowa o świadczenie ustug telekomunikacyjnych jako przykład wptywu administracji publicznej na kształtowanie, podejmowanie i realizację kontraktów w sferze prawa cywilnego, [w:] D.R. Kijowski, P.J. Suwaj (red.), Kryzys prawa administracyjnego, t. 3, Wypieranie prawa administracyjnego przez prawo cywilne, red. A. Doliwa, S. Prutis, Warszawa 2013. 
bezwzględnie zobowiązany do uiszczenia odszkodowania związanego z ulgą przyznaną abonentowi za okres od dnia zawarcia umowy do jej rozwiązania. Prowadziło to do sytuacji, że konsument zawierając umowę $\mathrm{z}$ operatorem nie miał możliwości - w razie zmiany zdania, jeszcze przed rozpoczęciem jej wykonywania - rozwiązania kontraktu bez opłacenia kwoty całości ulgi, którą w praktyce przyznaje się każdemu abonentowi. Jednocześnie nie zmieniła się część powyższego przepisu umożliwiająca roszczenie o zapłatę odszkodowania (do wysokości przyznanej ulgi) w przypadku rozwiązania umowy przez usługobiorcę, z jego winy, i już po rozpoczęciu jej realizacji.

Ponadto, dokonano zmiany maksymalnego okresu, na który konsument może zawrzeć umowę o świadczenie usług telekomunikacyjnych. Uczyniono to poprzez dodanie do art. 56 p.tel. ustępu 4a, który określa, że początkowy okres obowiązywania umowy, zawieranej z danym dostawcą usług na czas określony, nie może być dłuższy niż 24 miesiące. Jest to niejako ochrona abonentów przez nierozważnym podpisywaniem wieloletnich kontraktów, których rozwiązanie wiązało się z koniecznością zwrotu przyznanej ulgi abonamentowej. Z drugiej jednakże strony, w literaturze wskazuje się, że może to doprowadzić do zmiany dotychczas funkcjonującego modelu udostępniania usług abonamentowych w połączeniu ze sprzedażą aparatów telefonicznych ${ }^{12}$. Tego rodzaju sprzedaż polega na takim wyliczaniu kwoty abonamentu, która pokrywa (zawiera) miesięczne „raty” za aparat telefoniczny, sprzedawany za cenę zdecydowanie poniżej jego wartości rynkowej. Taka „konstrukcja” umożliwiała konsumentom nie posiadającym jednorazowo „dużej” kwoty pieniężnej na zakup (z zasady kosztownego) aparatu telefonicznego i spłacanie należności (w ramach abonamentu) w dłuższej perspektywie czasowej (np. 36 miesięcy).

\section{Elektroniczna forma umów}

Wprowadzono też zmianę p.tel., umożliwiającą zawieranie umów o świadczenie usług telekomunikacyjnych w drodze elektronicznej (wcześniej możliwe to było jedynie na piśmie), za pomocą formularza udostępnionego na stronie internetowej dostawcy usług ${ }^{13}$. Niewątpliwie jest to próba ułatwienia kontaktu między usługodawcą i usługobiorcą, a co za tym idzie usprawnienia i przyśpieszenia procesu zawierania kontraktów. Dotychczas - po przeprowadzeniu negocjacji i dojściu przez strony umowy do porozumienia - dostawca usług przedstawiał (bądź przesyłał tradycyjną drogą pocztową) treść umowy, którą strona potwierdzała własnoręcznym podpisem. Natomiast po nowelizacji, możliwe jest zawarcie

${ }_{12}$ M. Rogalski, Zmiany w zakresie umów o świadczenia ustug telekomunikacyjnych, „Internetowy Kwartalnik Antymonopolowy i Regulacyjny” 2013, nr 5, s. 75.

${ }_{13}$ Zob. art. 56 ust. 2 p.tel. 
umowy za pomocą formularza elektronicznego, i nie jest wymagane dodatkowe pisemne oświadczenie woli abonenta. Warto przy tym zauważyć, iż prawodawca nie przewidział innego rodzaju drogi elektronicznej niż formularz. Nie możliwe zatem będzie zawarcie umowy poprzez korespondencję elektroniczną (umowa $\mathrm{w}$ formacie pliku tekstowego) w ramach systemu teleinformatycznego przedsiębiorcy telekomunikacyjnego, za pomocą faksu, jak również telefonicznie (bez własnoręcznego podpisu na umowie zawartej w drodze telefonicznego porozumienia stron).

\section{Prawo abonenta do informacji}

Prawem podmiotowym usługobiorcy telekomunikacyjnego jest uzyskanie aktualnej i rzetelnej informacji o świadczonych usługach, w tym ich jakości. Już dotychczasowa regulacja p.tel. zawierała szereg obowiązków informacyjnych względem konsumentów, a nowelizacja jeszcze „poszerzyła” zakres tych zobowiązań.

Przede wszystkim, należy wskazać na obowiązek dostawcy publicznie dostępnych usług telekomunikacyjnych do publikowania aktualnych informacji o jakości udostępnianych usług, a tym samym wskazano na prezesa UKE jako upoważnionego do żądania od przedsiębiorców aktualnych danych, w celu niedopuszczenia do pogorszenia się jakości usług oraz spowolnienia ruchu w sieciach telekomunikacyjnych ${ }^{14}$.

Ponadto, przedsiębiorcy udostępniający usługę z dodatkowym świadczeniem (np. telefoniczne informatory, horoskopy, porady) są zobowiązani podawać - wraz z numerem tej usługi - cenę za jednostkę rozliczeniową albo połączenie oraz nazwę podmiotu realizującego owe „świadczenie dodatkowe”"15.

Konsument ma też prawo do informacji o przekroczeniu ustalonego w umowie tzw. ,progu kwotowego" ${ }^{16}$ dla każdego okresu rozliczeniowego (bądź miesiąca kalendarzowego). Przepis art. 64 ust. 5 p. 1 i 2 p.tel. określa, iż przekroczenie progu kwotowego zobowiązuje usługodawcę do natychmiastowego poinformowania abonenta o fakcie jego przekroczenia oraz zablokowania (na żądanie) możliwości wykonywania połączeń i ich odbierania z numerów usług o podwyższonej opłacie. Niejako rozwinięciem tego uprawnienia jest nowelizacja p.tel. dotycząca usługi udostępniania sieci Internet $\mathrm{w}$ formie mobilnej. Zgodnie $\mathrm{z}$ art. 63 a tegoż aktu, przedsiębiorca świadczący dostęp do Internetu mobilnego jest obowiązany

14 Zob. art. 63 ust. 1 i 2 p.tel.

15 Zob. art. 64 ust. 1 p.tel.

16 „Próg kwotowy” w znaczeniu prawa telekomunikacyjnego, to nic innego jak umowne ustalenie kwoty pieniężnej za usługi świadczone poza ceną abonamentu, po której wydatkowaniu (przekroczeniu) powinno nastąpić poinformowanie - o tym fakcie - usługobiorcy. 
do oferowania pakietów transmisji danych oraz do natychmiastowego, nieodpłatnego informowania abonenta o przekroczeniu przezeń limitu transmisji danych.

Uprawnienia informacyjne użytkowników końcowych zawarte zostały również w art. 68 p.tel., zobowiązującym dostawców publicznie dostępnych usług telekomunikacyjnych do zapewnienia możliwości połączenia z konsultantem dostawcy, celem uzyskania informacji o alternatywnych taryfach (o ile takie są udostępniane).

Jednocześnie, ustawodawca zapewnił wykonywanie obowiązków informacyjnych poprzez ustalenie uprawnienia Prezesa UKE do żądania stosownych informacji ${ }^{17}$, a w razie odmowy ich udzielenia, możliwość zastosowania kary pieniężnej ${ }^{18}$ określonej w art. 209 ust. 1 p. 1, 4, 12a, 14a i art. 210 p.tel.

\section{Prawo do przeniesienia numeru}

Nowelizacja p.tel. przyznała abonentowi prawo do przeniesienia numeru między dostawcami usług telefonicznych, w terminie jednego dnia. Dotychczasowe rozwiązania również przewidywały prawo przenoszalności numeru, jednakże w nie tak krótkim okresie czasu i bez zagwarantowania instrumentów chroniących owe uprawnienie. Nowe uregulowania przewidują instytucję odszkodowania za niedotrzymanie powyższego terminu. Abonent może bowiem ubiegać się o jednorazowe odszkodowanie (od dotychczasowego operatora) za każdy dzień zwłoki, W wysokości 1/4 sumy opłat miesięcznych, liczonej według rachunków z ostatnich trzech okresów rozliczeniowych. Przykładowo zatem, przy dotychczasowym abonamencie $\mathrm{w}$ wysokości 120 zł miesięcznie, za każdy dzień zwłoki należna jest kwota 30 zł. Podobne rozwiązanie zastosowano w przypadku abonentów usługi przedpłaconej (prepaid - na tzw. „kartę”). Przewiduje się, iż odszkodowanie w takim przypadku wyniesie (za każdy dzień zwłoki) 1/4 sumy wartości doładowań konta $z$ ostatnich 3 miesięcy ${ }^{19}$. Prawo podmiotowe konsumenta do uzyskania odszkodowania chronione jest niejako podwójnie, albowiem w przypadku, gdyby opóźnienie w przeniesieniu numeru nastąpiło z winy „nowego” operatora, dotychczasowy usługodawca jest nadal zobowiązany do wypłaty odszkodowania konsumentowi, jednakże przysługuje mu roszczenie zwrotne skierowane do podmiotu, który zawinił ${ }^{20}$. Prawodawca przewidział również sytuację, gdyby doszło do przeniesienia numeru między operatorami bez zgody abonenta. W takim przypadku, za każdy dzień od dnia aktywacji numeru w nowej sieci, abonent ma prawo żądania od nowego dostawcy odszkodowania $w$ wysokości 1 12 średniej

\footnotetext{
17 Zob. art. 6 ust. 1 p.tel.

18 zob. art. 6 ust. 2 p.tel.

19 Zob. art. $71 \mathrm{~b}$ ust. 2 p.tel.

${ }^{20}$ Ibidem, zdanie ostatnie.
} 
opłaty miesięcznej, liczonej na podstawie rachunków z trzech ostatnich okresów rozliczeniowych albo odpowiednio - $\mathrm{w}$ ramach usługi przedpłaconej $-\mathrm{z}$ trzech ostatnich doładowań ${ }^{21}$.

\section{Ochrona prywatności i danych osobowych}

Prawo do ochrony prywatności i danych osobowych w urządzeniach końcowych (komputerach, tabletach, smartfonach) wiąże się ściśle z dostępem do tzw. plików cookies. „Ciasteczka” umieszczone w urządzeniach abonentów pozwalają na dostęp do informacji o charakterze prywatnym. Nowelizacja p.tel. wzmocniła ochronę powyżej wskazanych praw podmiotowych użytkowników końcowych, poprzez nałożenie na przedsiębiorców obowiązku informowania abonenta o celach przechowywania danych oraz o możliwości samodzielnego określenia warunków przetwarzania danych za pomocą ustawień oprogramowania zainstalowanego w urządzeniu końcowym. Przepis znowelizowanego art. 173 p.tel. wskazuje, iż dostęp do cookies jest możliwy pod trzema warunkami. Po pierwsze, że abonent zostanie w sposób jednoznaczny, łatwy i dla niego zrozumiały o celach i możliwości określenia warunków przechowywania danych. Po drugie, że przechowywana informacja lub proces uzyskiwania do niej dostępu nie spowoduje zmian konfiguracyjnych w urządzeniu końcowym abonenta oraz - po trzecie - pod warunkiem wyrażenia zgody na dostęp ${ }^{22}$. Analizowana zmiana dotyczy sposobu wyrażania przez abonenta woli. O ile dotychczas, mógł on wyrazić jedynie sprzeciw, o tyle aktualnie konieczne jest uzyskania uprzedniej zgody jeszcze przed wprowadzeniem i rozpoczęciem przetwarzania danych.

Prawo do prywatności (ochrony danych w urządzeniu końcowym) wzmocnione zostało normą wynikającą z art. 174 p.tel. określającą niejako formalną prawidłowość zgody abonenta. Mianowicie, nie może być ona domniemywana lub dorozumiewana $\mathrm{z}$ oświadczenia woli o innej treści, ale też może być w każdym czasie (i bez ponoszenia dodatkowych kosztów) wycofana. Takie brzmienie przepisu jest zbieżne z zamierzeniami prawodawcy, który w uzasadnieniu do projektu nowelizacji stwierdził, iż

Zgoda nie może być wyrażona w sposób „milczący” lub poprzez inne pasywne działanie. W związku z powyższym należy uznać, iż właściwie poinformowany abonent lub użytkownik końcowy może podjąć świadomą decyzję co do wyrażenia zgody (poprzez dokonanie odpowiednich ustawień lub pozostawieniu ich na domyślnym, umożliwiającym przetwarzanie danych poziomie) lub jej braku, za pomocą ustawień przeglądarki, aplikacji o podobnej funkcjonalności lub konfiguracji samej usługi ${ }^{23}$.

${ }^{21}$ Zob. art. $71 \mathrm{~b}$ ust. 3 p.tel.

22 Zob. art. 173 ust. 1 p.tel.

${ }^{23}$ Uzasadnienie do rządowego projektu ustawy z dn. 23.07.2012 o zmianie ustawy - Prawo telekomunikacyjne oraz niektórych innych ustaw, Druk Sejmowy nr 627 (do art. 147 p.tel.) 
Zasadna wydaje się teza, że prawo do prywatności i ochrony danych osobowych abonentów usług telekomunikacyjnych jest nie tylko prawem podmiotowym, ale i posiada cechy publicznego prawa podmiotowego. Wprowadzony do ustawy Prawo telekomunikacyjne przepis art. 174a formułuje bowiem obowiązek organu administracji w przedmiocie ochrony danych osobowych w urządzeniach końcowych (a tym samym ustala możliwości żądania skutecznej ochrony). Przede wszystkim, w sytuacji naruszenia danych osobowych przez usługodawcę, a jednocześnie nie zawiadomienia abonenta o tym fakcie, Generalny Inspektor Danych Osobowych powinien nałożyć, w formie decyzji, obowiązek przekazania usługobiorcom będącym osobami fizycznymi informacji o: charakterze naruszenia danych, danych kontaktowych dostawcy, zalecanych środkach mających złagodzić niekorzystne skutki naruszenia ochrony danych, działaniach zaradczych podętych przez operatora, skutkach naruszenia ochrony danych oraz opisie środków naprawczych zalecanych przez przedsiębiorcę ${ }^{24}$.

\section{Dostęp do usług i udogodnień dla osób niepelnosprawnych}

Opisywane zmiany prawa telekomunikacyjnego formułują niezwykle szeroką ochronę praw osób niepełnosprawnych w zakresie dostępu do usług telekomunikacyjnych. Przede wszystkim, zmieniono zakres przedmiotowy i podmiotowy ustawy, poprzez dodanie do art. 1 ust. 1 punktu 13 określającego, iż ustawa określa wymagania dotyczące udogodnień dla osób niepełnosprawnych w zakresie dostępu do usług telekomunikacyjnych, a także zmieniono definicję publicznie dostępnej usługi telefonicznej (art. 2 pkt 30 p.tel.) poprzez wskazanie, że może ona obejmować korzystanie ze specjalnych udogodnień przez osoby niepełnosprawne. Najważniejsze jednak jest dodanie przepisu art. 79 c tego aktu, określającego obowiązek dostawców publicznie dostępnych usług telekomunikacyjnych zapewnienia użytkownikom niepełnosprawnym dostępu do świadczonych przez siebie usług na takim poziomie, jaki jest udostępniany większości abonentów. Jest to zmiana o tyle istotna, że dotychczas taki obowiązek nałożony był tylko na przedsiębiorców wyznaczonych, a nie - jak aktualnie - na wszystkich dostawców. Konsekwencją powyższego rozwiązania powinno być udostępnianie przez dostawców usług, które mogą być udostępniane na urządzeniach końcowych (telefonach, komputerach itp.) przystosowanych dla osób niepełnosprawnych (np. z wykorzystaniem funkcji zoom, głośnego czytania czy też głosowego wprowadzania poleceń).

${ }^{24}$ Zob. art. 174a ust. 6 i 7 p.tel. 


\section{Podsumowanie}

Reasumując, „ostatnia” nowelizacja Prawa telekomunikacyjnego formułuje szereg gwarancji prawnych ochrony praw podmiotowych konsumenta usług telekomunikacyjnych. Odnoszą się one do ochrony konsumenta usług telekomunikacyjnych jako strony kontraktu, problematyki zawierania umów w formie elektronicznej, ochrony prawa abonenta do rzetelnej informacji, ochrony prawa do przeniesienia numeru do innego operatora w terminie jednego dnia, ochrony prywatności i danych osobowych abonenta oraz ułatwiania dostępu do usług i udogodnień osobom niepełnosprawnym. Jednocześnie, można potwierdzić istnienie konkretnych instrumentów prawnych ochrony praw abonenckich. Ochrona praw konsumentów została potwierdzona brakiem możliwości dochodzenia odszkodowania przez przedsiębiorcę (jeśli rozwiązanie umowy nastąpiło przed rozpoczęciem udostępniania usług) oraz uniemożliwieniem zawierania skrajnie niekorzystnych - pod względem długości obowiązywania - kontraktów z abonentami. Ułatwiono też sposób zawierania umów, poprzez dodanie możliwości użycia drogi elektronicznej. Poza tym, ograniczono termin do przeniesienia - przez przedsiębiorcę - numeru telefonicznego do jednego dnia, zwiększono prawo do prywatności, poprzez ograniczenie dostępu do plików cookies oraz wzmocniono ochronę praw osób niepełnosprawnych, zobowiązując każdego dostawcę publicznej usługi telekomunikacyjnej do takiego kształtowania usług, aby były dostępne za pomocą urządzeń przystosowanych dla tychże osób. Co więcej, określono szereg kar za niedopełnienie (głównie przez przedsiębiorców) wskazanych obowiązków i sformułowano szereg zadań właściwych organów. 